RESEARCH ARTICLE

\title{
DNase treated DNA multiplex polymerase chain reaction assay for rapid detection of viable food borne pathogens
}

\author{
L. Mahesha N. Sigera Nadugala ${ }^{*}$, Sudip K. Rakshit ${ }^{2}$ \\ Food Engineering and Bioprocess Technology Programme, Asian Institute of Technology, SERD, P.O. Box 4 Klong Luang, \\ Pathumthani 12120, Bangkok, Thailand.
}

Revised: 19 April 2007 ; Accepted: 15 May 2007

\begin{abstract}
The main objective of this work was to develop methods to overcome the problems associated with rapid detection of food borne pathogens using PCR based techniques. A multiplex PCR method was developed as a solution to the problem of having to test for one organism at a time. DNaseI enzyme treatment followed by PCR [DNase Treated DNA (DTD) PCR] was experimented with to find a solution to the problem of false positive results obtained by amplification of DNA from dead cells. Four sets of primers were used for detection of eaeA, hly, invA and gryB genes of frequently occurring food borne pathogens Escherichia coli O157:H7, Listeria monocytogene, Salmonella enterica and Vibrio parahaemolyticus respectively. Experiments proved that DNaseI has the ability to remove DNA from dead cells without causing any damage to the DNA present inside live cells. DNaseI at a level of $10 \mathrm{U} / 100 \mu \mathrm{L}$ was found to remove DNA sourced from $5 \times 10^{7}$ dead cells in food systems within one hour of incubation. In the specificity test no interferences or non-specific amplification was observed when the multiplex protocol was tested with 89 strains of bacteria. The method developed was found to be sensitive to a minimum cell count of $10^{2}$ cells in both pure cultures and in artificially spiked food systems. There was no interference or inhibitory actions when the protocol was applied to shrimps. Thus, this DTD multiplex PCR assay can be practically applied for simultaneous identification of viable cells of four important pathogens namely E. coli O157:H7, S. enterica, L. monocytogenes and V. parahaemolyticus.
\end{abstract}

Keywords: detection, DNaseI, DTD multiplex PCR, food borne pathogens.

\section{INTRODUCTION}

The major cause of food poisoning results from bacteria. Ninety percent of the cases of food poisoning each year is caused by Salmonella spp., Listeria monocytogenes, Vibrio parahaemolyticus, Diarrheagenic Escherichia coli, Staphylococcus aureus, Clostridium perfringens, Campylobacter, Bacillus cereus and Shigella dysenteriae ${ }^{1}$. The percentage of transmission of Salmonella spp., L. monocytogenes, V. parahaemolyticus and Diarrheagenic E. coli through food items is 95, 99, 95 and $85 \%$ respectively $^{2}$. These four bacteria are important because they cause gastrointestinal diseases in humans, paticulary since the infections may result in life threatening sequelae such as salmonellosis, listeriosis, gastroenteritis and hemolytic uremic syndrome (HUS) respectively and these outbreaks occur very frequently around the world. Increased public awareness of health related issues and economic impacts of contaminated food and resulting illness have led to greater efforts to develop more sensitive methods of pathogen detection and identification.

Traditional methods, which are highly reliable and accurate to detect food borne bacteria often rely on time consuming growth in culture media, followed by isolation, biochemical identification, and sometimes serology. The absence of rapid, cost effective methods for bacterial detection in food items with a short shelf life poses particular difficulties for the implementation of effective food quality management systems in the modern market where there is a very rapid demand for food. It is well known that PCR is one of the most promising analytical tools in food safety control and clinical analysis because of its specificity and sensitivity ${ }^{3,4}$. However, conventional PCR methods do not distinguish viable cells from dead cells. The DNA extracted from cells killed by heat or other treatments will serve as a template for PCR many days after cell viability has been lost ${ }^{4,5}$. The presence of dead cells therefore limits the use of PCR for microbiological monitoring in food samples.

* Corresponding author 
Several authors have attempted to detect only viable cells by detection of mRNA using Reverse Transcriptase PCR (RT-PCR) ${ }^{6-9}$. DNA-PCR, however, has been found to provide stronger amplification signals compared to RT-PCR at the corresponding time points with the same PCR primer set, indicating a lower efficiency of RNA amplification compared to that of $\mathrm{DNA}^{3}$. The selective detection of viable but not dead bacteria is a major issue in nucleic acid-based diagnostics ${ }^{10}$. DNase treated DNA PCR (DTD PCR) methods have been attempted to eliminate such contaminating DNA from dead cells prior to the isolation of template DNA, to improve the overall fidelity of such detection methods ${ }^{11}$. In these preliminary experiments the harvested bacterial cells were exposed to crude DNaseI treatment to degrade the exogenous DNA released from completely lysed cells or the DNA still trapped in partially lysed cells. There is a need to prove that the DNA present inside the intact cells, which are likely viable cells, are spared.

Although PCR is rapid and specific, the process could become cumbersome when applied to numerous samples with various potential targets. To minimize time and materials, primers can be combined in a single reaction tube to form a multiplex-PCR (MP-PCR) ${ }^{12}$ which can simultaneously detect numerous target genes in a single sample.

In this study we report the development of a cheaper, faster and more sensitive alternative method than the commonly used RT-PCR method, which is more reliable than the conventional DNA based PCR method for prediction of the presence of possible viable pathogens in food. We also report the development of a highly specific four gene targeted MP-PCR assay which would be useful for simultaneous detection of the four highly problematic food borne pathogens; S. enterica, L. monocytogenes, $V$. parahaemolyticus and E. coli $\mathrm{O} 157: \mathrm{H} 7$ targeting the following genes inv $\mathrm{A}, h l y$, gry $\mathrm{B}$, eae $\mathrm{A}$, respectively.

\section{METHODS AND MATERIALS}

Bacterial strains and culturing: A total of eighty nine bacterial strains (Table 4) representing nine strains of E. coli, ten strains of Listeria, twelve strains of Salmonella and nineteen strains of Vibrio were included in this study. Additionally thirty nine strains of other bacteria which include food borne pathogens (closely related to target organisms and non related target organisms) and bacteria that are important in the food industry were also included. All strains were cultured in $10 \mathrm{~mL}$ of tryptic soy broth yeast extract medium (TSBYE) (Difco Laboratories, Detroit, MI, USA) and incubated under aerobic conditions overnight at $36 \pm 1^{\circ} \mathrm{C}$.
DNA extracts preparation: DNA extracts used as templates in PCR amplifications were prepared by Triton X-100 method. Bacterial DNA extracts were prepared according to the manufacturer's instructions (Easy DNA kit, Invitrogen Co., San Diego, USA). The procedure involved concentrating cells from a $7 \mathrm{~mL}$ aliquot of late log phase culture. The final DNA extract was dissolved in $50 \mu \mathrm{L}$ of ultra pure nuclease free water (Seromed ${ }^{\circledR}$ ).

Preparation of heat killed cells: In developing the DTD multiplex PCR system, heat treated cells were taken as the model cells to represent the "non cultivable cells" (dead cells with intact cell covering). According to preliminary experiments that were done in the Bioprocess lab in the Asian Institute of Technology, Thailand, it was proven that a heat treatment at $100{ }^{\circ} \mathrm{C}$ for $10 \mathrm{~min}$ in a constant temperature water bath produce dead cells with intact cell covering. Growth of the cells that were subjected to heat treatment was tested on TSBYE agar and cell covering was observed under light microscope.

PCR primers: Seven sets of primers were selected for this study based on the virulence gene sequences and other specific gene sequences, generating amplicons ranging from 285 to $1,087 \mathrm{bp}$ in length (Table 1). The sequences of three primer sets $(O 157$, eae $A$, gry $B)$ were obtained from reference materials and sequences of the other four primer sets (ehxA, hly, invA, toxR) were developed in the Bioprocess lab of Asian Institute of Technology, Thailand. Primers were prepared by Bioservice Unit of BIOTEC, Thailand and hydrated to a stock concentration of $100 \mathrm{pmole} / \mu \mathrm{L}$ using sterile TE buffer (10 mM Tris-HCl, 1mM EDTA). An aliquot of the primer stock solution was diluted to a working concentration of 50 pmole/ $\mu \mathrm{L}$ using sterile TE buffer. The stock and working primer solutions were stored in $50 \mu \mathrm{L}$ aliquots at $-20{ }^{\circ} \mathrm{C}$ until required.

Multiplex DNA amplification: Multiplex PCR was performed in $50 \mu \mathrm{L}$ reactions in $0.2 \mathrm{~mL}$ thin walled PCR tubes. The reaction mixtures contained $25 \mu \mathrm{L}$ of Hotstar Taq master mixture (1.25 U Taq DNA polymerase, $1.5 \mathrm{mM} \mathrm{MgCl}_{2}, 10 \mathrm{X}$ PCR buffer, dNTPs $200 \mu \mathrm{M}$ each), $0.25 \mu \mathrm{L}$ of each forward and reverse primers, $1 \mu \mathrm{L}$ of template DNA and ultra pure water to bring the final volume to $50 \mu \mathrm{L}$. The PCR procedure was performed in a PCR Thermocycler (Biometra ${ }^{\mathrm{TM}}$ Personel). The protocol performed consisted of three stages: Stage 1:1 cycle of $95{ }^{\circ} \mathrm{C}$ for $10 \mathrm{~min}$; Stage 2: 34 cycles of $95{ }^{\circ} \mathrm{C}$ for $45 \mathrm{~s}$, $45^{\circ} \mathrm{C}$ for $1 \mathrm{~min} 30 \mathrm{~s}$ and $72{ }^{\circ} \mathrm{C}$ for $1 \mathrm{~min}$ and $15 \mathrm{~s}$; Stage 3 : $72{ }^{\circ} \mathrm{C}$ for $5 \mathrm{~min}$ and $4{ }^{\circ} \mathrm{C}$ holding temperature. The PCR amplification products were visualized in $2 \%$ agarose gels (Analytical grade, Promega) stained with ethidium bromide $(0.2 \mu \mathrm{g} / \mathrm{mL})$ using UV transilluminator. In this 
Table 1: Summary of the primers used in this study

\begin{tabular}{|c|c|c|c|c|}
\hline Species & Target gene & PCR primers' sequences $\left(5^{\prime}-3^{\prime}\right)$ & Product size & Reference \\
\hline \multirow[t]{6}{*}{ E. coli $\mathrm{O} 157: \mathrm{H} 7$} & ehxA gene & ehxA1: TCT GAG CAG CTT AAC CAG CT & $398 \mathrm{bp}$ & 13 \\
\hline & & ehxA2: GAT TCA AGC TGC TTA GCT CG & & \\
\hline & eae gene & O157-F: CAG GTC GTC GTG TCT GCT AAA & $1,087 \mathrm{bp}$ & 14 \\
\hline & & O157- F: TCA GCG TGG TTG GAT CAA CCT & & \\
\hline & *nt $27-410$ & eae A1:GAC CCG GCA CAA GCA TAA GC & $384 \mathrm{bp}$ & 15 \\
\hline & of eaeA gene & eae A2: CCA CCT GCA GCA ACA AGA GG & & \\
\hline \multirow[t]{2}{*}{ L.monocytogenes } & hly & hly1: TAT ACC ACG GAG ATG CAG TG & 482 bp & 13 \\
\hline & gene & hly2: GCC GAA GTT TAC ATT CAA GC & & \\
\hline \multirow[t]{2}{*}{ S. enterica } & invA gene & invA1: TCT CTA CTT AAC AGT GCT CG & $685 \mathrm{bp}$ & 13 \\
\hline & & invA2: TGG TAT AAG TAG ACA GGG CG & & \\
\hline \multirow[t]{4}{*}{ V. parahaemolyticus } & tox $\mathrm{R}$ gene & toxR1: TGT ACG ATT AGG AAG CAA CG & 622 bp & 13 \\
\hline & & toxR2: AAC GTA GCG TTC AAT GCA CT & & \\
\hline & gryB gene & VP-F : CGG CGT GGG TGT TTC GGT AGT & & \\
\hline & & VP-R : TCC GCT TCG CGC TCA TCA ATA & $285 \mathrm{bp}$ & 16 \\
\hline
\end{tabular}

Table 2: Different combinations of primer sets tested in different multiplex PCR systems

\begin{tabular}{|c|c|c|c|}
\hline Multiplex system 1 & Multiplex system 2 & Multiplex system 3 & Multiplex system 4 \\
\hline $\operatorname{gryB}(285 \mathrm{bp})$ & $\operatorname{gryB}(285 \mathrm{bp})$ & ehxA (398 bp) & hly (482 bp) \\
\hline eaeA (384 bp) & hly (482 bp) & hly (482 bp) & $\operatorname{tox} \mathrm{R}(622 \mathrm{bp})$ \\
\hline hly (482 bp) & $\operatorname{inv} \mathrm{A}(685 \mathrm{bp})$ & $\operatorname{tox} \mathrm{R}(622 \mathrm{bp})$ & $\operatorname{inv} \mathrm{A}(685 \mathrm{bp})$ \\
\hline $\operatorname{invA}(685 \mathrm{bp})$ & 0157 (1087 bp) & $\operatorname{inv} \mathrm{A}(685 \mathrm{bp})$ & 0157 (1087 bp) \\
\hline
\end{tabular}

particular experiment four different combinations of primer sets (Table 2) were tested to obtain a well defined suitable multiplex PCR system with higher specificity towards target organisms, better separation of amplicons on gels and broader range of identification. Also two commercially available PCR master mix kits from Biorad and Qiagen were tested to detect the most suitable PCR master mix for industrial application in multiplex PCR detection systems.

Preparation of liquid food extract: Shrimps were shelled and whole meat was homogenized in a blender (National). $90 \mathrm{~mL}$ of TSBYE broth was added to $25 \mathrm{~g}$ of shrimp meat. Filtrate of boiled shrimp sample was taken as the liquid food extract.

Sensitivity and specificity for primers: The primers were tested for their sensitivity for simultaneous detection of S. enterica, L. monocytogenes, $V$. parahaemolyticus and $E$. coli $\mathrm{O} 157: \mathrm{H} 7$ in various concentrations $\left(10^{\circ}-10^{9}\right.$ bacterial cells $\mathrm{mL}^{-1}$ of ultra pure water/liquid food extract). They were also tested for their specificity against 89 different strains of bacteria (Table 4) which included food borne pathogens (closely related to target organisms and non related organisms) and bacteria that are important in the food industry.

DTD multiplex PCR amplification: Developed DTD multiplex PCR system was tested for the conditions necessary for simultaneous detection of live target organisms and the ability to eliminate DNA that yield from dead cells. Live cells of three organisms were separately mixed with heat killed cells of one organism in ultra pure water and liquid food extract according to the matrix given in Table 3 and treated with $10 \mathrm{U}$ of DNaseI enzyme for $1 \mathrm{~h}$ before extracting DNA by Triton $\mathrm{X}-100$ methods. Extracted DNA was dissolved in $10 \mu \mathrm{L}$ ultra pure water and multiplex PCR amplification was done as described in the previous section. 
Table 3: Different combinations of cells used in the experiment for testing sensitivity of DNaseI treated multiplex PCR for heat killed cells (HKC) and live cells (LC)

$\begin{array}{lllll}\text { Bacterial strains } & \text { Combination } 1 & \text { Combination 2 } & \text { Combination } 3 & \text { Combination } 4 \\ \text { S. enterica } & \text { HKC } & \text { LC } & \text { LC } & \text { LC } \\ \text { L. monocytogenes } & \text { LC } & \text { HKC } & \text { LC } & \text { LC } \\ \text { E. coli O157:H7 } & \text { LC } & \text { LC } & \text { HKC } & \text { LC } \\ \text { V. parahaemolyticus } & \text { LC } & \text { LC } & \text { LC } & \text { HKC }\end{array}$

Table 4: Results of PCR specificity experiments with multiplex system against different food related micro-organisms

\begin{tabular}{|c|c|c|c|c|c|c|c|}
\hline \multirow{3}{*}{ S.No. } & \multirow{3}{*}{$\begin{array}{l}\text { Bacterial strains } \\
\text { (Source) }\end{array}$} & \multicolumn{5}{|c|}{ PCR results } & \multirow[b]{3}{*}{$\begin{array}{c}\text { invA } \\
(685 \mathrm{bp})\end{array}$} \\
\hline & & & & Primers & & & \\
\hline & & $\begin{array}{c}g r y \mathrm{~B} \\
(285 \mathrm{bp})\end{array}$ & $\begin{array}{c}\text { eaeA } \\
(384 \text { bp) }\end{array}$ & $\begin{array}{c}\text { O157 } \\
\text { (1087 bp) }\end{array}$ & $\begin{array}{c}e h x \mathrm{~A} \\
(398 \mathrm{bp})\end{array}$ & $\begin{array}{c}\text { hly } \\
\text { (482 bp) }\end{array}$ & \\
\hline 1. & $\begin{array}{l}\text { E. coli } \\
\text { (ATCC 25922) }\end{array}$ & - & - & - & - & - & - \\
\hline 2. & $\begin{array}{l}\text { E. coli (Wild type ) } \\
\text { (AFRIMS) }\end{array}$ & - & - & - & - & - & - \\
\hline 3. & $\begin{array}{l}\text { E. coli (JM 109) } \\
\text { (BPT) }\end{array}$ & - & - & - & - & - & - \\
\hline 4. & $\begin{array}{l}\text { E. coli. }(\mathrm{DH} 5 \alpha) \\
\text { (BPT) }\end{array}$ & - & - & - & - & - & - \\
\hline 5. & $\begin{array}{l}\text { E. coli } \mathrm{O} 157: \mathrm{H} 7 \\
\text { (ATCC 43890) }\end{array}$ & - & + & + & + & - & - \\
\hline 6. & $\begin{array}{l}\text { E. coli (Rosetta) } \\
\text { (BPT) }\end{array}$ & $\begin{array}{l}- \\
-\end{array}$ & - & - & - & - & \\
\hline 7. & E. coli (TISTR 73) & - & - & - & - & - & - \\
\hline 8. & $\begin{array}{l}\text { E. coli (Wild type) } \\
\text { (Mahidol) }\end{array}$ & - & - & - & - & - & \\
\hline 9. & E. coli & - & - & - & - & - & - \\
\hline 10. & $\begin{array}{l}\text { L. monocytogenes } \\
\text { (ATCC 35152) }\end{array}$ & - & - & - & - & + & - \\
\hline 11. & $\begin{array}{l}\text { L.monocytogenes } \\
\text { (DMST 17303) }\end{array}$ & - & - & - & - & + & - \\
\hline 12. & $\begin{array}{l}\text { L. monocytogenes } \\
\text { (DMST 4553) }\end{array}$ & - & - & - & - & + & - \\
\hline 13. & $\begin{array}{l}\text { L. innocua } \\
\text { (DMST 9011) }\end{array}$ & - & - & - & - & - & - \\
\hline 14. & $\begin{array}{l}\text { L. grayi } \\
\text { (DMST 15840) }\end{array}$ & - & - & - & - & - & - \\
\hline 15. & L. welshimeri (DMST 10828) & - & - & - & - & - & - \\
\hline 16. & L. solanaceae & - & - & - & - & - & - \\
\hline 17. & $\begin{array}{l}\text { L. murrayi } \\
\text { (DMST 4580) }\end{array}$ & - & - & - & - & - & - \\
\hline 18. & $\begin{array}{l}\text { L. ivonivii } \\
\text { (DMST 9012) }\end{array}$ & - & - & - & - & - & - \\
\hline
\end{tabular}




\begin{tabular}{|c|c|c|c|c|c|c|c|}
\hline \multirow{3}{*}{ S.No. } & \multirow{3}{*}{$\begin{array}{l}\text { Bacterial strains } \\
\text { (Source) }\end{array}$} & \multicolumn{5}{|c|}{ PCR results } & \multirow[b]{3}{*}{ 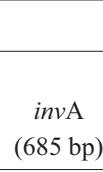 } \\
\hline & & \multirow[b]{2}{*}{$\begin{array}{c}g r y \mathrm{~B} \\
(285 \mathrm{bp})\end{array}$} & \multicolumn{3}{|c|}{ Primers } & \multirow[b]{2}{*}{$\begin{array}{c}\text { hly } \\
\text { (482 bp) }\end{array}$} & \\
\hline & & & $\begin{array}{c}\text { eaeA } \\
(384 \mathrm{bp})\end{array}$ & $\begin{array}{c}\text { O157 } \\
(1087 \mathrm{bp})\end{array}$ & $\begin{array}{c}e h x \mathrm{~A} \\
(398 \mathrm{bp})\end{array}$ & & \\
\hline 19. & $\begin{array}{l}\text { L. seeligeri } \\
\text { (DMST) } \\
\text { S. enterica }\end{array}$ & - & - & - & - & - & - \\
\hline 20. & $\begin{array}{l}\text { Serovar Typhimurium } \\
\text { (ATCC 14028) }\end{array}$ & - & - & - & - & - & + \\
\hline 21. & $\begin{array}{l}\text { Serovar Typhimurium } \\
\text { (ATCC 13311/TISTR 292) }\end{array}$ & - & - & - & - & - & + \\
\hline 22. & $\begin{array}{l}\text { Serovar Typhimurium } \\
\text { (DMST 15674) }\end{array}$ & - & - & - & - & - & + \\
\hline 23. & $\begin{array}{l}\text { Serovar Typhimurium } \\
\text { (ATCC 19430) }\end{array}$ & - & - & - & - & - & + \\
\hline 24. & $\begin{array}{l}\text { Serovar Choleraesuis } \\
\text { (ATCC } 10708 \text { / DMST 8014) }\end{array}$ & - & - & - & - & - & + \\
\hline 25. & $\begin{array}{l}\text { Serovar Paratyphi A } \\
\text { (DMST 15673) }\end{array}$ & - & - & - & - & - & + \\
\hline 26. & $\begin{array}{l}\text { Serovar Enteritidis } \\
\text { (DMST 15676) }\end{array}$ & - & - & - & - & - & - \\
\hline 27. & $\begin{array}{l}\text { Serovar Paratyphi B } \\
\text { (DMST 7090) }\end{array}$ & - & - & - & - & - & + \\
\hline 28. & $\begin{array}{l}\text { Salmonella sp. } \\
\text { (TISTR 96) }\end{array}$ & - & - & - & - & - & - \\
\hline 29. & $\begin{array}{l}\text { Salmonella sp. } \\
\text { (Burapha) }\end{array}$ & - & - & - & - & - & + \\
\hline 30. & $\begin{array}{l}\text { Salmonella sp } \\
\text { (Burapha) }\end{array}$ & - & - & - & - & - & + \\
\hline 31. & $\begin{array}{l}\text { Salmonella sp. } \\
\text { (Burapha) }\end{array}$ & - & - & - & - & - & + \\
\hline 32. & $\begin{array}{l}\text { Salmonella sp. } \\
\text { (Burapha) }\end{array}$ & - & - & - & - & - & + \\
\hline 33. & $\begin{array}{l}\text { V. parahaemolyticus } \\
\text { (AFRIMS- BH01-0124) }\end{array}$ & + & - & - & - & - & - \\
\hline 34. & $\begin{array}{l}\text { V. parahaemolyticus } \\
\text { (Burapha 1) }\end{array}$ & + & - & - & - & - & - \\
\hline 35. & $\begin{array}{l}\text { V. parahaemolyticus } \\
\text { (Burapha 2) }\end{array}$ & + & - & - & - & - & - \\
\hline 36. & $\begin{array}{l}\text { V. parahaemolyticus } \\
\text { (Burapha } 3 \text { ) }\end{array}$ & + & - & - & - & - & - \\
\hline 37. & $\begin{array}{l}\text { V. parahaemolyticus } \\
\text { (DMST 15285) }\end{array}$ & + & - & - & - & - & - \\
\hline 38. & $\begin{array}{l}\text { V. alginolyticus } \\
\text { (DMST 14800) }\end{array}$ & - & - & - & - & - & - \\
\hline 39. & $\begin{array}{l}\text { V. cholerae } 0139 \\
\text { (AFRIMS) }\end{array}$ & - & - & - & - & - & - \\
\hline 40. & $\begin{array}{l}\text { V. cholerae (Ogawa) } \\
\text { (AFRIMS) }\end{array}$ & - & - & - & - & - & - \\
\hline
\end{tabular}




\begin{tabular}{|c|c|c|c|c|c|c|c|}
\hline \multirow{3}{*}{ S.No. } & \multirow{3}{*}{$\begin{array}{l}\text { Bacterial strains } \\
\text { (Source) }\end{array}$} & \multicolumn{5}{|c|}{ PCR results } & \multirow[b]{3}{*}{$\begin{array}{c}i n v \mathrm{~A} \\
(685 \mathrm{bp})\end{array}$} \\
\hline & & & & Primers & & & \\
\hline & & $\begin{array}{c}g r y \mathrm{~B} \\
(285 \mathrm{bp})\end{array}$ & $\begin{array}{c}\text { eaeA } \\
(384 \mathrm{bp})\end{array}$ & $\begin{array}{c}\text { O157 } \\
\text { (1087 bp) }\end{array}$ & $\begin{array}{c}e h x \mathrm{~A} \\
(398 \mathrm{bp})\end{array}$ & $\begin{array}{c}\text { hly } \\
\text { (482 bp) }\end{array}$ & \\
\hline 41. & $\begin{array}{l}\text { V. cholerae (Inaba) } \\
\text { (AFRIMS-56190) }\end{array}$ & - & - & - & - & - & - \\
\hline 42. & V. vulnificus (Biotype 1) & - & - & - & - & - & - \\
\hline 43. & V. vulnificus (Biotype 2) & - & - & - & - & - & - \\
\hline 44. & $\begin{array}{l}\text { V. vulnificus } \\
\text { (DMST 5852) }\end{array}$ & - & - & - & - & - & - \\
\hline 45. & $\begin{array}{l}\text { V. harvey } \\
\text { (KCTC 2717) }\end{array}$ & - & - & - & - & - & - \\
\hline 46. & $\begin{array}{l}\text { V.campbelli } \\
\text { (Mahidol) }\end{array}$ & - & - & - & - & - & - \\
\hline 47. & $\begin{array}{l}\text { Vibrio sp. } \\
\text { (Burapha) }\end{array}$ & + & - & - & - & - & - \\
\hline 48. & $\begin{array}{l}\text { Vibrio sp. } \\
\text { (Burapha) }\end{array}$ & + & - & - & - & - & - \\
\hline 49. & Vibrio sp. & + & - & - & - & - & - \\
\hline 50. & $\begin{array}{l}\text { Vibrio sp. } \\
\text { (Burapha) }\end{array}$ & + & - & - & - & - & - \\
\hline
\end{tabular}

\footnotetext{
a In addition to the bacterial strains listed in this table, we also obtained negative PCR results for all the above six PCR primer sets for the following bacterial strains: Shigella dysenteriae (AFRIMS 102/2), Sh. dysenteriae (Burapha), Sh .boydii (AFRIMS), Sh. sonnei (ATCC 25931), Sh. sonnei (Burapha), Sh. flexineri (ATCC 12022), Sh. flexineri (Burapha), Klebsiella oxytoca (AFRIMS), Klebsiella pneumoniae (ATCC 13883), Klebsiella pneumoniae (Burapha), Staphylococcus aureus (ATCC 13565/TISTR 29), Staphylococcus aureus (ATCC 25923), Staphylococcus aureus (ATCC 2913), Streptococcus pyogenes (ATCC 19615), Streptococcus pyogenes (Burapha), Bacillus cereus (ATCC 11778/TISTR 686), B. circulans (ATCC 9995/TISTR 906), B. subtilis (TISTR 25), B. stearothermophilis (UPCC116/CSIRO (FS 1518)), Enterococcus faecalis (ATCC 19433), Enterobacter amnigenus (AFRIMS), Enterobacter aerogenes (ATCC 13048), Enterobacter (ATCC 23355), Pseudomonas aeruginosa (ATCC 27853), P. stutzeri (AFRIMS), P. putida (Mohidol), P. deminuta (BPT), Flavobacterium colomnare (Burapha), Flavobacterium sp. (Burapha), Serratia marcesseus (Burapha), Edwardsiella tarda (Burapha), Haemophilus influenzae (AFRIMS), Corynebacterium glutamicum (ATCC 21475), Lactobacillus plantarum (TISTR 541), L. casei (TISTR 1463), L. brevis (TISTR 855), L. lactis (TISTR 1464), L. acidophilus (TISTR 1338), Aeromonas hydrophila (Burapha)

b AFRIMS - Armed Forces Research Institute of Medical Sciences, ATCC - American Type culture collection, BPT - Bioprocess Technology culture collection, DMST - Department of Medical Sciences, Thailand, KCTC - Korean Collection for Type Cultures, Burapha - Burapha University culture collection, Mahidol - Mahidol University culture collection.
}

${ }^{c}(+)$ - presence of expected PCR product; (-) - absence of expected PCR product

\section{RESULTS}

\section{Multiplex DNA amplification}

Theoretical melting temperatures of all the primers used ranged from 45 to $55{ }^{\circ} \mathrm{C}$. Therefore individual PCR reactions were carried out at three different temperatures $\left(45{ }^{\circ} \mathrm{C}, 50{ }^{\circ} \mathrm{C}\right.$, and $55{ }^{\circ} \mathrm{C}$ ) (gel pictures not given). At the three tested annealing temperatures all the primers produced PCR products. However at the annealing temperature of $45{ }^{\circ} \mathrm{C}$ all the primers gave better amplification and the PCR bands showed the highest intensity. Hence the annealing temperature of $45{ }^{\circ} \mathrm{C}$ was used in the multiplex system as well (gel pictures not given). Multiplex system 1 gave the expected PCR products for all four target organisms and the amplicons 
were well separated on the $2 \%$ agarose gel. Multiplex system 2 also gave four amplicons, but one of the four bands was an unexpected band (200 bp approximately) which may be a result of misamplification. Multiplex system 2 did not produce the expected band for $E$. coli O157:H7 at the size of 1,087 bp. Multiplex system 3 also gave the expected PCR products for the target organisms, but separation of bands was not very clear. Multiplex system 4 yielded only three prominent expected bands. This system also did not yield the PCR product expected for $E$. coli $\mathrm{O} 157: \mathrm{H} 7$ at the size of 1,087 bp but there were some faint extra bands presented in the gel due to misamplification. In both multiplex systems ( 2 and 4$)$ that used 0157 primer pair for detection of E. coli O157:H7 the expected PCR amplicon was not produced. This may be due to primer-dimer formation. Based on the results of these experiments multiplex systems 2, 3, 4 were not chosen for further studies. Multiplex PCR system 1 was developed with four primer pairs namely gryB, eaeA, hly and $\operatorname{inv} A$.

The efficiency of amplification was ideal in the tested extension temperatures of $72{ }^{\circ} \mathrm{C}$ and $74^{\circ} \mathrm{C}$. Commercial PCR master mix kits from Qiagen and Biorad gave amplification products under all tested conditions. The intensity of the PCR products was higher with Qiagen PCR master mix kit than with Biorad kit when other parameters were kept constant. Hence the Qiagen PCR master mix kit was used for further studies.

\section{Sensitivity and specificity of primers}

The main objective of the sensitivity test was to find the minimum detectable level of cells of target organism from pure cultures and from liquid food extracts. It should be noted here that theoretically PCR based methods are

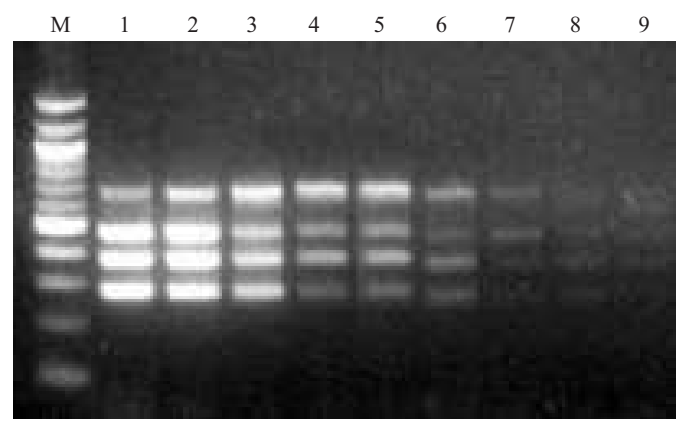

Figure 1: Sensitivity of developed multiplex PCR system on different cell counts of bacteria from pure cultures.

Lane M: 100 bp molecular size marker. Lane 1-9: E.coli O157:H7, L. monocytogenes, $V$. parahaemolyticus and S. enterica multiplex PCR products with known concentration $\left(10^{8}-1\right.$ cells $)$. expected to yield good results even if a single DNA is present. However, efficiency of extraction of DNA, the efficiency with which primers interact with the template at low concentrations, the random chances of occurrence in the diluted test samples etc. make this difficult. This is also pointed out by the fact that enrichment media is required in the conventional plate count method. According to the results of gel electrophoresis (Figures 1 and 2) it is clear that this system is able to detect a minimum level of $10^{2}$ cells of all target organisms from pure cultures. The cell level $10^{1}$ also produced very faint bands which were not clearly documented by the available gel documentation system. However, in industrial applications this will be a better starting point which can be reconfirmed by the reamplification of PCR products or by use of conventional methods if needed.

Specificity of the developed multiplex PCR method was checked against 89 strains of bacteria. Some of the strains were either closely related to target bacteria, not related to target bacteria or related to other food industry bacteria. Results of this experiment are given in Table 4. None of the specific primer pairs gave cross amplification with the other organisms tested to date. In the case of eaeA primer of $E$. coli it produced an amplicon with a size of $384 \mathrm{bp}$ with the E. coli O157:H7 strain. It also produced a prominent band with other E. coli strains which has a size of between $400-500 \mathrm{bp}$. These results were due to the reason that eaeA primer pair targets a region that is conserved between enteropathogenic and shiga toxigenic $E$. coli strains $^{15}$. This primer will help the detection of a wide range of diarrheagenic $E$. coli which are human pathogens. If further confirmation is needed with E. coli O157:H7 strain reconfirmation can be done with $e h x A$ and $\mathrm{O} 157$ primer sets which are highly specific to E. coli O157:H7. The specific primer (hly primers)

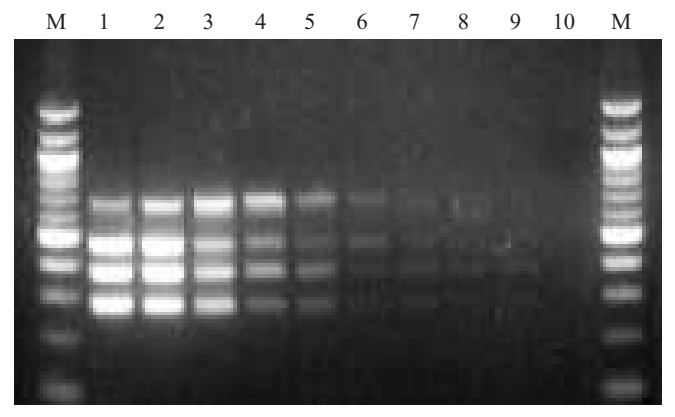

Figure 2: Sensitivity of developed multiplex PCR system on different cell counts of bacteria on shrimp.

Lane M: 100 bp molecular size marker. Lane 1-10: E.coli O157:H7, L. monocytogenes, V. parahaemolyticus and S. enterica multiplex PCR products with known concentration $\left(10^{9}-1\right.$ cells $)$. Lane M: $100 \mathrm{~b}$ bp molecular size marker. 


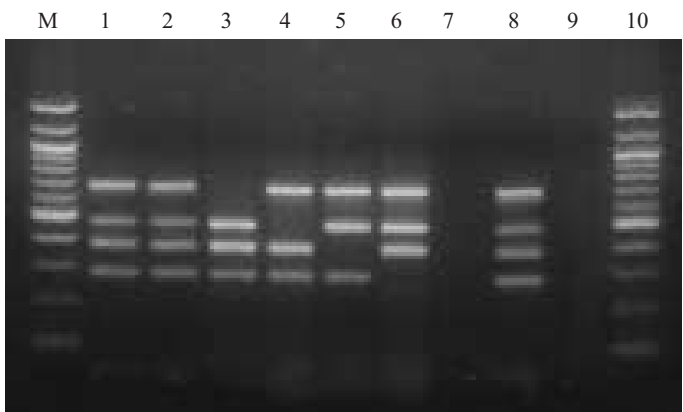

Figure 3: Sensitivity of developed DTD multiplex PCR system on different cell combinations (see Table 3 ) of target bacteria from pure cultures.

Lane M: 100 bp molecular size marker. Lane 1: Live cells of four bacteria with DNaseI treatment, Lane 2: live cells of four bacteria with out DNaseI treatment, Lane 3: Combination 1 with DNaseI treatment, lane 4: Combination 2 with DNaseI treatment, Lane 5: Combination 3 with DNaseI treatment, Lane 6: Combination 4 with DNaseI treatment, Lane 7: Heat killed cells of four bacteria with DNaseI treatment, Lane 8: Heat killed cells of four bacteria without DNaseI treatment, Lane 9: PCR negative control. Lane M: 100 bp molecular size marker.

used to detect L. monocytogenes was also confirmed to be highly specific in the developed multiplex PCR system. It did not show any cross amplification with other bacteria tested in the study. The primer pair produced the expected band of 482 bp size only with the tested strains of L. monocytogenes. The primer pair (invA) used for detection of Salmonella is specific to the species enterica. Species enterica includes several serovars. Most of these serovars are human pathogens which cause salmonellosis. The multiplex system was tested against six know serovars of Salmonella enterica species and five other unidentified Salmonella species. Except serovars Enteritidis all the other serovars gave the expected PCR product $685 \mathrm{bp}$. Theoretically serovar Enteritidis also should produce the PCR product as the primer pair is specific to species enterica. Negative result may be due to the degradation of extracted DNA which could not be reconfirmed. All the unidentified Salmonella species produced the expected PCR product (685 bp) which helps to confirm that they belong to species enterica. The primer pair invA was also tested with different species of Shigella that is closely related to Salmonella. None of the Shigella species tested gave PCR products. As the original paper reported ${ }^{16}$ the primer pair gry $B$ is highly specific to $V$. parahaemolyticus. It did not show any cross amplification with the other micro-organisms tested in the study. The primer pair is specific enough to differentiate between $V$. parahaemolyticus and $V$. alginolyticus which are reported to be closely related. All the unidentified Vibrio species showed the expected

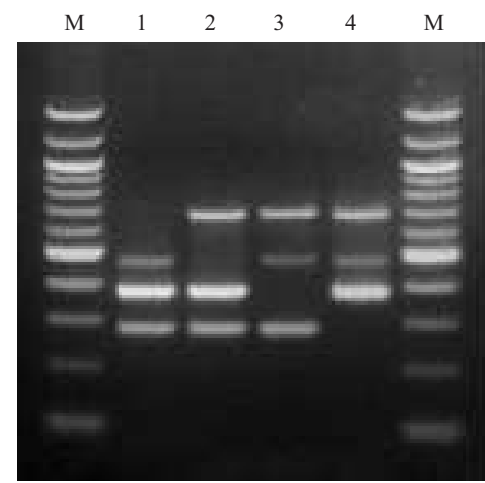

Figure 4: Sensitivity of developed DTD multiplex PCR system on different cell combinations (see Table 3) of target bacteria on shrimp.

Lane M: 100 bp molecular size marker, Lane 1: Combination 1 with DNaseI treatment, Lane 2: Combination 2 with DNaseI treatment, Lane 3: Combination 3 with DNaseI treatment, Lane 4: Combination 4 with DNaseI treatment, Lane M: 100 bp molecular size marker.

PCR product (285 bp) which confirms that they belong to species parahaemolyticus. Specificity of the developed multiplex system was tested with many other unrelated food borne pathogens and other food industry related micro-organisms. None of them produced any kind of PCR product. This confirms the specificity of the developed multiplex system.

\section{DNase Treated DNA (DTD) multiplex PCR amplification}

This experiment was conducted to test the ability of developed DTD multiplex PCR system to detect live cell DNA of target organisms and simultaneously digest the DNA in dead cells. The cell count was fixed at $5 * 10^{7}$ cells $/ 100 \mu \mathrm{l}$ for DNaseI treatment. The result in the Figures 3 and 4 show the ability of developed DTD multiplex PCR system to detect live cell DNA and the ability to remove the DNA that yield from dead cells which are represented by heat killed cells in this system.

\section{DISCUSSION}

The DTD multiplex system with pure cultures and artificially spiked food samples gave expected results and did not show any kind of inhibitory effect with the shrimp samples. The DNaseI treatment (10 U, one hour) is able to remove DNA yielding from $5 \times 10^{7}$ of dead cells, which is far beyond the expected level of cells in natural food systems. The results of the developed 
DTD multiplex PCR system reveal its ability to get rid of exogenous DNA released from completely lysed cells or partially lysed cells. DNaseI was capable of penetrating through the cell covering of non cultivable cells and degrade the DNA inside those cells too. DNaseI did not however degrade the DNA inside live cells. Its efficiency in spiked shrimp samples indicates that the DNA extraction methods, DNaseI activity and PCR conditions are not affected by the components of the shrimp. This system proved to be an effective method to be used in food systems to detect live food borne pathogens. Sensitivity studies gave the same result with pure cultures as well as artificially spiked food samples. It showed the ability of the developed tool to detect the minimum cell level of $10^{2}$ cells.

The major contribution of this study is the development of a PCR kit using a universal culture medium and four pairs of specific primers in the same PCR conditions for detection of four important food borne pathogens that occur very commonly in food systems. The application of DNaseI enzyme can be used to eliminate false positive results that DNA of dead cells would give. The protocol could be developed into a kit for routine analysis for food borne pathogen detection for industrial applications.

\section{Acknowledgement}

We are grateful to the Armed Forces Research Institute of Medical Sciences, Department of Medical Sciences (Thailand), Korean Collection for Type Cultures, Burapha University culture collection, and Mahidol University culture collection for providing the bacterial strains employed in this study.

\section{References}

1. Wagner A.B. (1989). Bacterial Food Poisoning. Texas Agricultural Extension Publication No. L-1540.

2. Mead P.S., Slutsker L. Dietz V., McCaig L.F., Bresee F.J. \& Shapiro S.C. (1999). Synopses: Food-Related Illness and Death in the United States. Centres for Disease Control and Prevention - Atlanta, Georgia, USA, 5:607-625 [Online]http://www.kcom.edu/faculty/chamberlain/ Website/foodborne.htm. Accessed : 22.11.04

3. McKillip J. \& Jaykus L. Drake M. (1999). Nucleic acid persistence in heat-killed Escherichia coli $\mathrm{O} 15: \mathrm{H} 7$ from contaminated skim milk. Journal of Food Protection 62 (8):839-844.

4. Nogva H., Dromtorp S., Nissen H. \& Rudi K. (2003). Ethidium monoazide for DNA-based differentiation of viable and dead bacteria by $5 \mathrm{~V}$-nuclease PCR. BioTechniques 34 (4): 804- 813.

5. Chaiyanan S., Huq A. \& Mangel T. \& Colwell R. (2001). Viability of the nonculturable Vibrio cholerae $\mathrm{O} 1$ and O139. Systematic and Applied Microbiology 24 (3): 331341.

6. McBain A., Bartolo R., Catrenich C., Charbonneau D., Ledder R., Richard A., Symmons S. \& Gilbert P. (2003). Microbial characterization of biofilms in domestic drains and the establishment of stable biofilm microcosms. Applied and Environmental Microbiology 69 (1): 177-185.

7. Van Beckhoven J., Stead D. \& van der Worf J. (2002). Detection of Clavibacter michiganensis subsp. Sepedoncus by amphinet RNA, a new technology based on real-time monitoring of NASBA amplicons with a molecular beacon. Journal of Applied Microbiology 93 (5): 890-899.

8. Bentsink L., Leone G., van Beckhoven J., van Schijndel H., van Gemen B. \& van der Worf J. (2002). Amplification of RNA by NASBA allows direct detection of viable cells of Ralstonia solanacearum in potato. Journal of Applied Microbiology 93 (4): 647- 655.

9. Novak J. \& Juneja V. (2001). Detection of heat-injury in Listeria monocytogenes Scott A. Journal of Food Protection 64 (11): 1343- 1379.

10. Rudi K., Nogva H., Moen B., Nissen H., Bredholt S., Moretro T., Naterstad K. \& Holck A. (2002). Development and application of new nucleic acid-based technologies for microbial community analyses in foods. International Journal of Food Microbiology 78 (12): 171- 180.

11. Mukhopadhyay U.K. \& Mukhopadhyay A. (2002). A low cost, rapid, sensitive and reliable PCR -based alternative method for predicting the presence of possible live microbial contaminants in food. Current science $\mathbf{8 3}$ 53-56.

12. Chamberlain J.S., Gibbs R.A., Ranier J.E., Nguyen P.N. \& Caskey C.T. (1988). Deletion screening of the Duchenne muscular dystrophy locus via multiplex DNA amplification. Nucleic Acids Research 16: 11141- 11156.

13. Hoa N.T.H. (2004). Multiplex polymerase chain reaction (PCR) for the detection of food pathogens. M.Sc. thesis (Thesis No-04-12). Asian Institute of Technology, Thailand.

14. Gannon V.P.J., Rashed M., King R.K. \& Golsteyn Thomas E.J. (1993). Detection and characterization of the eae gene of Shiga-like toxin-producing Escherichia coli by using polymerase chain reaction. Journal of Clinical Microbiology 31: 1268-1274.

15. Paton A.W. \& Paton J.C. (1998). Detection and characterization of shiga toxigenic Escherichia coli by using multiplex PCR Assays for $s t x 1$, stx2, eaeA, enterohemorrhagic $E$. coli hlyA, rfbO111, and $r f b \mathrm{O} 157$. Journal of Clinical Microbiology 36 (2): 598-620.

16. Venkateswaran K., Dohmoto N. \& Harayama S. (1998). Cloning and nucleotide sequence of the gryB gene of Vibrio parahaemolyticus and its application in detection of this pathogen in shrimp. Applied and Environmental Microbiology 64 (2): 681-687. 